\title{
Review on the Implementation and Localization of TBLT in China
}

\author{
Wensha Zheng
}

Postgraduate in Yangtze University, China

Received: 04 Apr 2021; Received in revised form: 21 May 2021; Accepted: 06 Jun 2021

(C2021 The Author(s). Published by TheShillonga. This is an open access article under the CC BY license (https://creativecommons.org/licenses/by/4.0/)

\begin{abstract}
Task-based language teaching approach is a popular and powerful teaching approach in foreign language teaching. However, the researches in its application and localization are rare. This article takes teachers 'and students' perspectives as study object, trying to find out their different or identical views about TBLT. What' more, the advice towards the mismatches is beneficial to the later study of TBLT in China. Researches find that teachers 'belief in FLT are not consistent to TBLT, and they have low confidence in implementing it. Students hold more positive views about TBLT, and they become more confident after a semester's learning. Advice suggest that more teacher training is needed, and it is important for teachers to interact with students both in class and out of class.
\end{abstract}

Keywords - TBLT Implementation; teachers'belief in TBLT; Students' understanding in TBLT.

\section{INTRODUCTION}

Task-based Language Teaching began in the 1980s and gradually matured in theory in the 1990s. It is a teaching approach that developed from Communicative Language Teaching. It shares the same beliefs that language should be learned as closed as possible to how it is used in real life. Since the 1990s, most Asian countries have adopted Task-based Language Teaching approach in foreign language teaching. In 2003, the National English Curriculum Standards for Senior High School (experimental draft) promulgated by the Ministry of Education explicitly proposed to use the TBLT approach in English classrooms.

Compared with the traditional grammar-translation teaching method, TBLT makes the process of language learning truly a process of students' active thinking and autonomous learning. Task-based teaching approach theoretically balances the conflict between language form and meaning and the conflict between improving language fluency, accuracy, and complexity. Therefore, once task-based teaching approach is proposed in China, it has become a focus of attention and research of English teaching and research personnel.

However, when TBLT is implemented and applied in classroom, a lot of problems arise. Some teachers do not know what a task should be, and how to design an authentic and useful task for students. Let alone the big scale of class, heave teaching pressure and testing pressure, and the mixed ability of students.

Hence, a lot of studies try to explore the predicament of implementation and localization of TBLT in EFL classroom. Generally, their studies focus on three parts: teachers' beliefs in TBLT; students' perception of TBLT; 
the applied bias or mismatches of TBLT in EFL classroom.

\section{Teachers' beliefs in TBLT}

As the core in a classroom, studies concerning teachers is first and foremost. In order to explore the actual implementation of TBLT, it is necessary for us to look at teachers' beliefs in TBLT.

Teacher beliefs, in Borg's (2001) view, refer to “teachers' pedagogic beliefs or those beliefs of relevance to an individual's teaching". Calderhead (1996) proposes five main categories of teacher beliefs: beliefs about learners and learning, beliefs about teaching, beliefs about subject, beliefs about learning to teach and beliefs about self and the teaching role. In a study which explores Hong Kong English teachers' beliefs in TBLT, Winnie Laifan Chan (2014) adapted the above frame, he investigates English teachers' beliefs about the English language, their beliefs about teaching English language, their beliefs about learning English language, their beliefs about the role of English teachers and their beliefs about English learners.

1.1 Strong beliefs but poor understanding and implementation

Teachers' strong belief in TBLT benefit to the implementation of it. Although some teachers may not have a clear understanding towards TBLT, but they are very willing to implement it, especially high school teachers. Yuying Liu and Tao Xiong (2016) studied 26 college EFL teachers for non-English major students, and their finds show that though there are constraints from various aspects (including, the teaching materials, large class size etc.) for the successful implementation of TBLT, TBLT received very positive feedback from teachers. Most of the teachers in this study hold positive views towards TBLT even though they have a low-level understanding of principles and practices of TBLT.

\subsection{Inconsistent teaching beliefs to TBLT}

Exception exists. There is a study show that even teachers may have a quite well understanding towards TBLT, but their own teaching style and beliefs may not be consistent to it. So, they will not use task-based teaching approach.
Winnie Laifan Chan (2014) investigated 10 Hong Kong secondary school English teachers. For each participant, there were initial interviews, pre-class-visit interviews, and post-class-visit interviews and at least two classroom observation. The researcher in the current study finds that, even though the English teachers have a good command of TBLT principles, they may not implement TBLT to its full extent, because their central beliefs and more strongly held beliefs may have an overriding influence. Two central beliefs: first, English lessons are to equip students well for assessment; second, exercises can prepare students well for assessment.

\subsection{Low beliefs and lack of confidence}

However, the fact is, most teachers do not even have clear command of TBLT, and their beliefs are not consistent with TBLT principles. And those factors directly lead to their low confidence towards TBLT.

Xinmin Zheng and Simon Borg (2014) investigated Three Chinese secondary school teachers of English from different level of school. They found that TBLT was defined in a narrow manner and was strongly associated with communicative activities, especially oral work involving pair and group work. One of the participants reported that:

Using TBLT meant increasing the opportunities I gave students to speak

English in pairs and groups. Tasks could only be used in moderation due to

the examination system and large class sizes.

They confine TBLT to a kind of teaching approach that only students' oral expression and cooperation ability can be improved, and they use TBLT just to create active classroom atmosphere. The reasons behind it are unsupported teaching conditions and teachers' low understanding towards TBLT.

Relatedly, Xuejun Ye (2018) investigated 13 English teachers in a private secondary school, and the participants reported that their incompetent proficiency in English, understanding TBLT and designing appropriate tasks 
impede their implementation of TBLT. The lack of confidence was extremely conspicuous in new teachers.

Similarly, Qi Chen and Clare Wright (2016) investigated 4 English teachers in a private high school, where the CLT is highly recommended. They found that even at a quite supported environment, that is no large-scale class, students' ability not so poor, and CLT approach is the main approach in this school, teachers' lack of confidence turned to be the most serious factor that impede the implementation of TBLT. Qi Chen and Clare Wright (2016):

Participants all felt constrained in using TBLT, which they ascribed to lack of professional development, despite the extensive training they all had during their first year of teaching in HSZC, and to a belief that TBLT was not always locally appropriate.

Participants also lacked confidence about their capacity for task design and achieving successful task outcomes; this was closely tied to concern over students' poor accuracy in written English in exams.

Not only university and middle school or high school teachers concern about their teaching ability and perception of TBLT, primary school teachers also have the problem about designing tasks and reasonably organize a TBLT class.

Dingfang Shu and Yan Zhu (2017) investigated two primary school English teachers in Shanghai, and one of the participants is foreign teacher came from Australia. They analyzed teachers' classroom discourse and did semi-interview and classroom observation. It is worth noticing that they use narrative frame and teacher-led discourse to do their research. The study found that both the two teachers used Task-supported teaching approach instead of task-based teaching approach. The two teachers' understanding of the task concept and the cognition of the task's function in language teaching directly affect their classroom teaching behavior. Therefore, to promote curriculum reform, it is necessary to develop and implement in-service teacher education projects based on specific teachers and school characteristics.

\section{STUDENTS' PERCEPTION ABOUT TBLT}

2.1 Students' low interest and understanding toward TBLT

Not only teachers' beliefs and implementation matter, students' perception on TBLT is also important, which influences their attitude and cooperation in English learning. Once teachers can grasp students' need and interest, get enough feedback, the language teaching will be gorgeous.

Jun Tang, Yunfan Yang and Luan Zhang (2016) investigated the applied bias of TBLT in several science and engineering universities, from the students' perspectives. According to their findings, many students know little about TBLT, and have low interest in it. Less than half of the students expressed their willingness to accept this kind of teaching method.

\subsection{Mismatches between teachers and students in terms of the implementation of TBLT}

In their comparative study (Yunfan Yang and Luan Zhang, 2016) between teachers' and students' perceptions on the task difficulty, measures to solve problems, teaching content in TBLT and the advantages of TBLT, teachers and students behaved quite different.

In general, teachers are more optimistic about the difficulty of accepting task-based teaching approach than students. When encountering difficulties in task-based teaching approach, most students tend to change tasks spontaneously, which will change the teaching objectives to a certain extent and leads to a certain deviation in teaching effects. In terms of the advantages and actual effects of task-based language teaching, the deviation is mainly manifested in whether it is helpful to academic performance. This shows that teachers may ignore or underestimate the advantages of improving academic performance, which may dilute the functional requirements of task-based teaching in the expected goals, deviate from the goals expected by the students, and 
ultimately affect the actual application deviation in teaching effect.

\subsection{Advice to the mismatches between teachers and students}

Jun Tang, Yunfan Yang and Luan Zhang (2016) further gave four advice:

1. Choose the appropriate part to teach in TBLT

2. Optimize the setting of difficulty

3. Cultivate students' sense of subjectivity

4. Strengthen the communication between teacher and students

John Harper and Handoyo Puji Widodo (2018) did a study in Shantou university, to investigate the mismatches between the instructor's stated purpose of the lesson and the students' perception of the purpose of the lesson. The participants in the study were students of Global Law English 2 (GLE-2) at Shantou University. The subject of this micro-evaluation was a TBLT-based law lesson. Their findings show that:

"most of the students enjoyed having in-class discussion in that they thought a discussion task as a learning platform for enriching their linguistic resources and knowledge because they could learn from each other."

So, they promote the negotiation between teachers and students. And balancing form-focused learning tasks and meaning focused learning tasks is badly needed inasmuch as both content and language are always integrated.

Although not many studies explore the effects of TBLT from the students' perspectives, the similarities of the above two studies can leave us some implications. Teachers should involve students to the design of task, and make appropriate task, if necessary, teachers can introduce to students the TBLT approach.

\subsection{Related studies abroad}

Some studies not conducted in China can provide us some experience and implications. Atefeh Hadi (2013) did a comparative study between English teachers' and English learners' perception. All the participants are adult learners. Opposite to Tang, Yang and Zhang's study (2016), Hadi (2013) found that learners have more positive views than teachers on TBLT implementation.

Learners believed that TBLT was more appropriate for small group work than teachers. Therefore, it can be claimed that compared with teachers, most students did not find text book materials suitable for task-based instruction.

Hadi also advocated the self-study of teacher and professional teacher training about TBLT.

YouJin KIM and Yeonjoo Jung (2017) did a study in a private university in Korea, tried to investigated the implementation of a new one-semester TBLT course from the feedback of students. Questionnaire and focus participant observation and interview were conducted. It is worth noticing that the instructor was a professional task-based teaching teacher, so the study can be seen as a pure research to study the perception and experience of students. After analyzing the data from questionnaire, it is implied that students liked the interactiveness of the tasks and the speaking practice.

This task focuses on a student orientation. This reminded me of my first day as a new student, attending the student orientation. It was interesting to compare my orientation and the orientation information provided in the task.

This comment suggests that when the task content focuses on something relevant to students' lives, they would more likely participate in using Korean, they may show more interest in completing the task. About the interview and observation of the focus participant, it shows that her confidence with task performance was increased. The focus participant and the other students changed their perceptions toward tasks over one semester as they became more accustomed to this approach.

YouJin KIM and Yeonjoo Jung (2017): "although the students' interest in participating in TBLT increased 
gradually, their beliefs about the usefulness of tasks for English learning and the effectiveness of TBLT compared to traditional instruction showed more variability."

We can see that no matter how different students performed in the acceptance or willingness to TBLT, they are all very keen to see obvious progress, that is, grade.

\section{IMPLICATION AND ADVICE}

\subsection{Teacher Training}

Since the studies show that many teachers did not know exactly what TBLT is, and young teachers face a problem of lacking confidence, and elder teachers have no access to get into understanding of TBLT, almost all the researchers advocate the professional teacher training about TBLT. (Pei Chen, 2009; Winnie Laifan Chan, 2014; Yuying Li and Tao Xiong, 2016; Xuejun Ye, 2018; Yuanhua Xie and Qiuli Chen, 2019...)

It is suggested that schools at all levels can take on more responsibilities for teacher development and training, so as to form a "dynamic, three-dimensional and sustainable development" teacher development model of the state, local governments at all levels, and schools.

(Pei Chen, 2009)

\subsection{Special Teaching Materials for TBLT}

The confusion and obsolescence of teaching materials is an important factor hindering teachers from implementing task-based teaching. In the interview, teachers all said that if they can use the teaching materials based on the task-based teaching, it will help them to implement this teaching mode more actively and accurately in the classroom. (Pei Chen, 2009)

Develop more teaching materials based on the concept of TBLT to reduce the psychological burden of teachers in implementing this method, enhance their confidence in operating tasks, and enable them to organically combine the theory and practice of TBLT, and truly improve the efficiency of foreign language teaching. (Yuanhua Xie and Qiuli Chen, 2019)

\subsection{Highlight Students' Participation}

Students' involvement and interest in TBLT in quite important, Dingfang Shu and Yan Zhu (2017) advocated that teachers should listen to students to adjust the teaching activities in classroom, and it is very important for teachers to interact with students both in class or out of class.

Teachers need to strengthen their understanding of students' ability and adaptability, and use it as a basis to develop application modules and implement task-based teaching activities with moderate difficulty; students should communicate with teachers in a timely manner when encountering difficulties, and effectively address their problems and needs Give feedback to teachers, and actively work with teachers to continuously optimize tasks in order to achieve the desired teaching effect.

(Jun Tang, Yunfang

Yang and Luan Zhang, 2016)

\section{CONCLUSION}

Since the concept of task-based language teaching was formally proposed in the early 1980s (Long, 1985), this language teaching practice concepts and methodology has not only received active attention from theoretical researchers, but has also been written into English curriculum standards in many countries and regions where English is a foreign language, and has been continuously tested in teaching practice. However, under the "global fever" wave of TBLT, one reality that we cannot ignore is that its implementation in English classrooms around the world is full of resistance, and successful cases are rare. Most studies on the factors affecting TBLT or CLT curriculum reform show that teachers' understanding and implementation of TBLT is the key to implementing task-based teaching. What's more, the participation and involvement of students also deserve our attention. Different studies to primary, middle and high schools and universities show that teachers generally hold a positive attitude towards TBLT, but their incompetent ability and 
lack of confidence will lead implementation to failure. So many researchers advocate for more professional training and there should be more negotiation between teachers and students to co-construct a task-based classroom.

\section{REFERENCES}

[1] Aliasin, S. H, Saeedi, Z, Pineh, A. J, \& Wan, P. The relationship between EFL teachers' perception of task-based language teaching and their dominant teaching style[J]. Cogent Education, 2019, 6(1):1-16.

[2] Chan WL. English Language Education and Assessment: Recent Developments in Hong Kong and the Chinese Mainland[M]: Springer Singapore, 2014: 17-34.

[3] Chen Q, Wright C. Contextualization and authenticity in TBLT: Voices from Chinese classrooms[J]. Language Teaching Research, 2016:1-22.

[4] Ellis R. Task-based language learning and teaching[M]. Oxford: Oxford University Press, 2003.

[5] Ellis R. Task-based language teaching: sorting out the misunderstandings[J]. International Journal of Applied Lingus, 2009, 19(3):221-246.

[6] Erlam R. 'I'm still not sure what a task is': Teachers designing language tasks $[\mathrm{J}]$. Language Teaching Research, 2016, 20(3):1-21.

[7] Hadi A. A Comparative Study of Iranian EFL Teachers and Learners Perspectives on Task-based Instruction[J]. Theory and Practice in Language Studies, 2013, 3(2): 300.

[8] Harper J, Widodo H P. Perceptual mismatches in the interpretation of task-based ELT materials: a micro-evaluation of a task-based English lesson[J]. Innovation in Language Learning and Teaching, 2020, 14(2): 114-132.

[9] Hu R. Task-Based Language Teaching: Responses from Chinese Teachers of English[J]. TESL-EJ, 2013, $16(4): 1-21$.

[10] Ji Yi, Pham T. Implementing task-based language teaching (TBLT) to teach grammar in English classes in China: using design-based research to explore challenges and strategies[J]. Innovation in Language Learning and Teaching, 2020(1):1-14

[11] Kim Y, Jung Y, Tracy-Ventura N. Implementation of a Localized Task-Based Course in an EFL Context: A Study of Students' Evolving Perceptions[J]. TESOL Quarterly, 2017, 51(3): 632-660.

[12] Littlewood W. The task-based approach: some questions and suggestions[J]. ELT Journal, 2004, 58(4): 319-326.

[13] Liu, Yuying \& Xiong, Tao. Situated Task-based Language Teaching in Chinese Colleges: Teacher Education[J]. English Language Teaching, 2016,9(5):22-32.

[14] Shimomura F. General Overview of TBLT and Its Applicability to the University English Classrooms in Japan[J]. International Journal of Education, 2014, (6):62-70.

[15] Tabatabaei O, Hadi A. Iranian EFL Teachers' Perceptions of Task-Based Language Pedagogy[J]. Higher Education of Social ence, 2011:1-9.

[16] Ye Xuejun. Task-based Language Teaching in Southwest China: Insider Perspectives from Secondary School Teachers[J]. Theory and Practice in Language Studies, 2018, 8(11):1415-1425.

[17] Zheng X, Borg S. Task-based learning and teaching in C hina: Secondary school teachers' beliefs and practices $[\mathrm{J}]$ . Language Teaching Research, 2014, 18(2): 205-221.

[18] 陈锫. 针对任务型教学实施现状的实验性研究 $[\mathrm{J}]$. 外 语研究, 2009, 114(2): 52-59.

[19] 丁艳. 中学英语教学中任务型教学法的实施 [J]. 上海教 育科研, 2007,234(4):85.

[20] 郭红梅. 任务型教学法在英语教学中的运用及制约因 素[J].教学与管理,2009,412(15):132-133.

[21] 刘春燕, 郭芯. 任务型教学在中小学英语教学中的中国 本土化研究 (英文) [J].Chinese Journal of Applied Linguistics,2020,43(02):205-218+250.

[22] 唐军, 杨云帆, 张变. 任务型教学在大学英语课堂中的 应用偏差与解决策略 [J]. 安徽警官职业学院学报, 2016, 15(3): 107-112.

[23] 吴文,潘康明.亚洲语境下的任务型语言教学研究 [J]. 
现代外语, 2012,35(3):312-318,330.

[24] 谢元花,陈秋丽. 高校英语教师对任务型教学的理解 与实施探究[J]. 现代外语, 2019, 42(2): 267-279.

[25] 赵宇欣.浅谈教师在任务型教学中所发挥的作用 [J]. 现代交际, 2018, 493(23): 189-190.

[26] 朱彦,束定芳.任务型语言教学中的教师信念和教师主 导话语研究[J]. 现代外语, 2017, 40(1): 125-136, 147. 